\title{
Het Woord dat standhoudt in een wereld die vergaat
}

\author{
M. Bergsma
}

'maar het Woord van de Heer blijft eeuwig bestaan' (1 Petrus 1:25a)

\section{Yolo}

You only live once. Het is een moderne levensfilosofie in een 'catch-phrase'. Wat ermee gezegd wordt, is dat je maar beter van het leven kunt genieten, want het is kort en als het voorbij is, is het voorbij. You only live once is een levensfilosofie met nihilistische trekken, de horizon van het leven is de dood. En achter de horizon is niets. En als er wel iets achter de horizon is, dan is het nu niet belangrijk genoeg om je er druk over te maken, want je bent te druk met uit het leven halen wat erin zit.

Vaak wordt gedacht dat gereformeerde christenen, als erfgenamen van de toch al niet te vrolijk ogende Calvijn, deze festivalcultuur van de moderne mens in goeden doen, willen komen verstoren. En je kunt natuurlijk redenen genoeg bedenken om dat te willen, maar onze core-business is niet het bederven van feestjes, gelukkig maar...

Die bestaat in iets anders, dat ons tegemoetkomt in de brief van Petrus aan de uitverkorenen, die als vreemdelingen verspreid leefden in wat nu het midden en noorden van Turkije is. Het bestaat uit het brengen van een boodschap van hoop. De gelovigen in Klein-Azië van toen waren zelf opnieuw geboren tot een levende hoop door de opstanding van Jezus Christus uit de doden, tot een onvergankelijke, ongerepte en onverwelkbare erfenis, die in de hemel bewaard werd voor hen (1 Petrus 1:4-5), geroepen om zich te laten gebruiken als levende stenen voor de bouw van een geestelijke tempel (1 Petrus 2:4), uitverkoren ook om de grote daden te verkondigen van Hem die u uit de duisternis heeft geroepen naar zijn wonderbaarlijke licht (1 Petrus 2:9). Levende hoop in een wereld die sterft.

Je kunt op allerlei plaatsen in de brief merken dat de druk op de 'pasgeboren' christenen om weer 'gewoon' mee te doen met de rest van de samenleving hoog was. De mensen om hen heen, hun buren en stadsgenoten begrepen niet waarom ze niet meer meededen aan wat Petrus noemt 'liederlijke uitspattingen' en daarom werd er kwaad over hen gesproken (1 Petrus 4:4). Het Woord 
van het evangelie dat hen levend gemaakt had en een bestendige hoop had gegeven, maakte tegelijk dat ze vreemdelingen werden in eigen land. Ze zijn mensen geworden die op reis zijn naar een betere bestemming. En dat geldt niet alleen voor toen, het geldt ook voor ons hier en nu. 'Here God, wij zijn vervreemden door te luisteren naar uw stem. Breng ons saam met uw ontheemden naar het nieuw Jeruzalem' (Jan Wit, Gezang 802 in het Nieuwe Liedboek).

Je zou het zo kunnen samenvatten: onze kerntaak als christenen is in Woord, maar ook met onze hele levensstijl verkondigen dat er een beter feest is, een feest dat ook door de dood en machten van de dood niet kan worden verstoord. Beter nog, ons leven is nieuw geworden door het Woord van God en we vertrouwen erop dat dat Woord zijn levendmakende kracht niet verliezen kan, omdat het het Woord van de Heer is.

\section{Het eeuwige Woord van God}

Maar het begint niet bij onze taak. Het begint bij het Woord van God. Het is door geloof in het Woord van God dat we opnieuw geboren worden tot een levende hoop. Het is door Gods levende en altijd blijvende Woord dat we opnieuw geboren worden uit onvergankelijk zaad. Dat Woord is het goede nieuws aangaande Jezus Christus. Door geloof hebben we deel aan het leven dat er is door zijn opstanding. En het bederf dat deze wereld regeert, is voor ons met Hem het graf ingegaan, zodat wij als vrijgekochten uit deze machten mogen leven, als mensen die leven met hoop op God. Het begint bij het Woord van God dat eeuwig blijft bestaan. En met dat Woord en vanuit dat Woord mogen wij leven in deze wereld.

Wanneer we van daaruit nadenken over wat dan de taak voor kerk en theologie is, dan is het allereerst dat we onszelf en ook de wereld aan onze vergankelijkheid herinneren en tegelijk onszelf en de wereld verkondigen dat er ook iets is dat nooit meer vergaat: het bevrijdende en vreugdevolle Woord van God. Dat betekent voor de verkondiging een kritische en tegelijk vreugdevolle taak. In zijn boek Being as communion legt John Zizioulas uit wat vanuit het perspectief van de oosters-orthodoxe theologie (met haar zwaartepunt in de tegenstelling dood en leven) de relatie tussen vergankelijkheid en zonde is; het is vanwege onze sterfelijkheid dat we ongeduldig dingen voor onszelf willen bemachtigen. Zonde is derhalve het egoïsme van het rusteloos voortgedreven worden door onze sterfelijkheid. De zonde en de macht van de dood horen bij elkaar. Niet alleen is de dood het loon van de zonde, het is ook andersom; vergankelijkheid drijft mensen ook tot zonde. Een theologie die deze reciproke relatie tussen zonde en dood niet rechtdoet, blijft ergens een geamputeerde theologie. Calvijn legt er in zijn uitleg van deze tekst in zijn oorspronkelijke context bij Jesaja 40 de nadruk op, dat de profeet de joden de 
vergankelijkheid van de mens voorhoudt om ze af te helpen van hun valse vertrouwen op eigen kracht of wijsheid. Het volk moet eerst omlaaggebracht worden. Het is de vraag of Calvijns neiging om deze tekst bijna uitsluitend te beperken tot de joden wel terecht is, maar zijn uitleg dat profetische verkondiging ook betekent dat er kritisch gesproken moet worden tot mensen zodat mensen vervolgens uitgenodigd kunnen worden om tot hun troost het Woord van het evangelie te ontvangen, is terecht. Dat wij mensen als gras zijn, maar dat het Woord van de Heer eeuwig is, betekent voor ons in kerk en theologie dat we kritisch mogen spreken zodat mensen uitgenodigd worden om met vreugde hun oude vergankelijke bestaan achter zich te laten en te leven uit het nieuwe leven dat ons geschonken wordt door geloof in het Woord van het evangelie van Jezus Christus.

Onze roeping is niet het bederven van feestjes, onze roeping is wel om mensen duidelijk te maken waarom aardse feestjes, hoe leuk en gezellig ook, uiteindelijk geen vervulling geven. Onze roeping is wel om te duiden waar het lege gevoel na het feestje vandaan komt en waarom sommige van onze feestjes onder de oppervlakte niet alleen leeg aanvoelen, maar ook onrechtvaardig (omdat Lazarus in onze tijd altijd voor deur ligt), duiden ook dat losbandigheid, wellust, dronkenschap geen losse incidenten zijn op feestjes die wat te gezellig werden, maar dat juist het grenzenloze waar onze feestjes toe neigen de kwade keerzijde is van een door mensen nooit te winnen gevecht tegen onze sterfelijkheid. En dan mogen we tegelijk mensen ook uitnodigen om te leven van iets dat niet vergaat, om het perspectief te kiezen van hoop op een onvergankelijke en ongerepte erfenis die niet verwelkt. We mogen onszelf en anderen voorhouden dat er een leven is door het Woord van de Heer, dat als nieuw leven in een vergankelijk bestaan gezaaid wordt en dat ons aanzet tot vurige liefde. Voor kerk en theologie een kritische en vreugdevolle taak.

\section{Drie voorwaarden om met het eeuwige Woord in een sterfelijke wereld te kunnen staan}

1 Zelf de kracht van het Woord kennen. Het lijkt een open deur, maar wat je zelf niet kent, kun je ook niet delen. In onze persoonlijke levens, maar ook in kerk en theologie is een levend vertrouwen in de kracht van het Woord van God onontbeerlijk. Het is het vertrouwen in het Woord dat van dode zondaars levende kinderen van God maakt. Zelf weten dat je hele bestaan hangt aan de weldaad van dit Woord is de sine qua non voor elke christen, en dus ook voor elke theoloog of verkondiger van dat Woord. Dat Woord is, om opnieuw Calvijn aan te halen, leven dat bereid is voor de doden, die dorstig zullen komen tot de fontein die hun voor ogen wordt gehouden; want de kracht die in God verborgen is, is ons geopenbaard door het Woord. 
Het betekent ook dat een defensieve houding ons niet past. Als het Woord het enige is dat niet vergaat, dan hoeven wij dus ook niet bang te zijn dat het de tand van onze tijd niet zal overleven. En dan mogen wij met dat Woord vrijmoedig in deze wereld staan. Wijzelf zijn sterfelijk, vergankelijk en zwak, maar het Woord van God dat ons in handen is gegeven is vol kracht, het is zelfs eeuwig. Een defensieve houding, ook in onze theologie, dat we vooral bezig zijn met bewaren wat er te bewaren valt, doet het eeuwige karakter van Gods Woord onrecht. Alles vergaat, ook onze theologieën, maar het Woord van God is eeuwig en vergaat nooit. Als we dat levende Woord niet meer vrijmoedig durven spreken in een vergankelijke wereld, dan is het een teken van slaperig of angstig geworden geloof.

2 Zelfeen vreemdeling geworden zijn. De brief van Petrus is geschreven aan christenen die als vreemdelingen verspreid leven, aan christenen die in een positie van machteloosheid verkeren.

Voorzover wijzelf (nog) vanuit een positie van comfort en zekerheid onze theologie bedrijven, voorzover kunnen we onszelf ook afvragen of de krachteloosheid van veel verkondiging en theologie niet ook daarmee te maken kan hebben. Waar we zelf niet (genoeg) bemerken dat wij zelf als gras zijn en dat onze bloemen afvallen, daar hebben we misschien ook te weinig gevoel voor de kracht van het Woord dat leven brengt waar nu nog de dood heerst. Misschien kunnen we de praktijk van onze theologie eens tegen dit licht houden. Het is een voorrecht om de rust en ruimte te hebben van theologische instituten en een kerkelijk leven dat daarvoor de ruimte biedt, maar wat zou er met onze theologie gebeuren als we bewust meer de verbinding zouden zoeken met situaties waarin onze vreemdelingschap tastbaarder is? Wat als onze theologie bewust meer vanuit de marge geschreven zou worden? Wat als we onze theologie meer bedrijven in de marge van kleine ploeterende missionaire initiatieven die veel van onze kerkgenootschappen rijk zijn? Wat als we onze theologie meer bedreven vanuit de context van huiskerken die in wijken en dorpen ontstaan? Wat als onze theologie meer zou opkomen uit de kleine kerken die het wel proberen maar die het nauwelijks lukt in de overgeleverde structuren voort te gaan? Wat als we onze theologie meer bedreven in nauwe samenwerking met de migrantenkerken in onze samenleving? Je zou ook kunnen zeggen: misschien moeten we van de kerkelijke nood maar een deugd maken en er dan op vertrouwen dat het waar is wat Petrus zegt: de mens is als gras, maar het Woord van de Heer blijft eeuwig bestaan.

3 Liefde. De oproep die Petrus doet met een beroep op de nieuwe geboorte van christenen uit het onvergankelijke zaad door het levende en altijd blijvende Woord van God, is een oproep tot onderlinge liefde. Zouden we niet veel meer merken van de kracht van Gods levendmakende Woord als we deze 
oproep veel serieuzer zouden nemen, juist in een steeds meer polariserende cultuur? Polarisatie in de wereld van politiek en cultuur, ook veel kerkelijke polarisatie, die althans sociologisch gesproken vaak parallelle trekken vertoont, is een teken van de vergankelijkheid van ons menselijk bestaan. Liefde is het teken dat het levende en altijd blijvende Woord van God zijn werk doet. En als de liefde ontbreekt, moet de conclusie zijn dat er alleen het gewone vergankelijke zaad is, dat zal sterven. Maar waar de liefde is, daar is hoop: voor mensen, voor de kerk, want de liefde is uiteindelijk onweerstaanbaar.

\section{Nieuw leven in een stervende wereld}

We gaan de 40-dagentijd tegemoet. Dan staan we stil bij het wonder dat Jezus, de Zoon van God zich vereenzelvigde met een door kwaad en zonde stervende wereld, om midden in die wereld nieuw leven te geven uit onvergankelijk zaad. Wij die nu leven, hebben allemaal het leven uit vergankelijk zaad. Wij die geloven in Christus, die voor ons de dood inging en opstond, hebben nog een nieuw leven, dat nooit meer zal vergaan. Want de mens is als gras, maar het Woord van de Heer blijft eeuwig bestaan.

M. Bergsma is predikant van de Singelkerk, de christelijke gereformeerde kerk van Utrecht-Centrum 